\title{
Migration In The Early '90s: Italy Coping With Albanian Illegal Emigration
}

\author{
Jeta Goxha, PhD Candidate \\ Department of Law and Political Science, Faculty of Economics and Social \\ Sciences, SHPAL “Pavarësia” Vlorë, Albania
}

doi: 10.19044/esj.2016.v12n11p254 URL:http://dx.doi.org/10.19044/esj.2016.v12n11p254

\begin{abstract}
This article aims to study the role that Italy played in confronting the migratory flows in the early 90s, with a separate analysis of the Albanian case. The Italian diplomacy policies regarding the problems caused by the confrontation of the illegal immigration phenomenon will be analyzed. This research intends to provide an overview of the political and social relations between the two countries. The problem is analyzed through a bibliographic search, treating the issues in a historical and political framework. The scientific contributions on the issue under consideration are mainly the Italian legislation, archival resources taken from the Ministry of Foreign Affairs archives, reports and strategies drawn up by the Italian government, in order to avoid social and economic problems. The study method used is qualitative. This author's interest relates to the conviction that Italy has played an important role in confronting the Albanian emigrants even though most of the time it appears without a concrete plan and at the same time contradictory. While writing this paper we will review all factors and consequences that were derived in this phenomenon.
\end{abstract}

Keywords: Albanian emigration, Italian Policies, Diplomatic relationship, Repatriations

\section{Introduction}

The human nature is tempted to seek much better living conditions. This is one of the main motivations to emigrating, but not the only one. The reasons vary, economic, political, social and cultural factors influenced the population movements. Economic inequality and also the great changes that occurred in the international scenario, served as a catalyst for the citizens influx towards the developed countries. The Albanian people, who had lived in total isolation, saw leaving Albania as the only option, choosing the way of emigration. 
The fall of the communist regimes in Central and Eastern Europe was a sign of hope for the citizens of these countries. They had gained freedom, the highest price, but on the other hand this freedom provoked major concerns for the consequences that may entail. From this point of view, Italy was one of the countries which faced most of the effects of these movements, also due to its geographical position. Fall of the Berlin Wall for Eastern Europe marks a reason for hope, for a better life.

After the fall of the harsh regime, the first changes were reflected inside the Albanian state. These changes were reflected even beyond the geographical boundaries of the country.

\section{The embassies Case: The issue of Popa family}

On December 1985, just eight months after the death of Enver Hoxha, Popa family, two brothers and four sisters entered the Italian Embassy in Tirana. The Albanian authorities demanded the unconditional surrender of the sixth, but Italy insisted that they be allowed to leave Albania. Popa family issues drew the international attention and also became a motive for the freezing of the relationships between the two countries. A few hours after the notification of accession of Albanian Citizens in the Italian embassy territory, the embassy was surrounded by policemen, being placed completely under the control of the Interior Ministry. According to the evidence gathered by that time that evening, the Italian television news broadcasted describing the event as a possible cause of diplomatic crisis between the two countries.

After these years the relationship between the two countries are inclined to improve, despite the incident of 1985, which often becomes subject of discussion between representatives of the twoOn December 1985, just eight months after the death of Enver Hoxha, Popa family, two brothers and four sisters entered the Italian Embassy in Tirana. The Albanian authorities demanded the unconditional surrender of the sixth, but Italy insisted that they be allowed to leave Albania.

Popa family issues drew the international attention and also became a motive for the freezing of the relationships between the two countries. A few hours after the notification of accession of Albanian Citizens in the Italian embassy territory, the embassy was surrounded by policemen, being placed completely under the control of the Interior Ministry. According to the evidence gathered by that time that evening, the Italian television news broadcasted describing the event as a possible cause of diplomatic crisis between the two countries.

After these years the relationship between the two countries are inclined to improve, despite the incident of 1985, which often becomes subject of discussion between representatives of the two countries. We also 
notice this, in the talks between our prime minister, Reiz Malile and Italy’s labor minister, Rino Formica (The archive of the Ministry of Foreign Affairs, the fund Name: Italy, File 483, 1987).

In the meeting that was held with Minister Formica, our Prime Minister Reiz Malile has cleared the objectives that Albania wants to achieve with its neighbor. Our government wishes, that our bilateral relations be developed in a friendly way; in general they will develop positively, but we must do even more, because there is more work to be done by the two ambassadors.

Despite the efforts of both Parties to avoid this issue, involuntarily, it became a thorn for both parties in this period. Reiz Malile clearly expressed his appreciation on the positive expansion between the two countries ... the bilateral cooperation with Italy that we have considered a priority, because we are neighbors.

Malile cannot stand negligent of this issues that has aggravated the bilateral relations, preferred to face the problem, he expressed "You mentioned the incident in the sealed form, but I will speak openly, for the six persons whom are introduced in your embassy, it is not important, they do not have value. It is important that both parties are trying to improve the diplomatic relations"( The archive of the Ministry of Foreign Affairs, the fund Name: Italy, File 483, 1987, Pg 76-77).

Starting from that period, our country understands that could not continue its superficial relationship or break off the diplomatic relations with Italy, because the transboundary cooperation became a priority, also the historical ties that exist between our countries and our common interests.

In the second of July 1990, the communist regime suffered a great shock, where about six thousand residents of the capital and other districts flocked to the foreign embassies of France, of FRG and Italy in Tirana (Kastriot Dervishi, Albanian State History 1912-2005, 2006, pg 785).

This event was the result of a terrible hatred of the Albanian people against the dictatorship. The motive of the event was a true political motive, despite the fact that poverty and unemployment had reached its peak, also the economic crisis was in the most critical point (Agim Leka, AcademicusInternational Scientific Journal MMXIII, pg 201).

Major economic and social difficulties that occurred in Albania after the fall of the communist regime paved the way to the mass exodus in 1991, more than 30,000 refugees turned to Italy. Albania's massive departures flooding the Adriatic coast, until this situation was threatening Italy. The Italian government faced with this situation, at the same time frightened by the massive floods, needed to find an immediate solution, to deter the illegal immigration and at the same time to repatriate those who illegally had reached the Italian coasts. 
For all the reasons above mentioned, both countries decided to put aside antagonisms and choose the path of cooperation, which apriori seemed positive, even more easily done than the relations between Bulgaria and Italy.

\section{The orientation of the Albanian government to establish diplomatic relations with neighbors}

Enver Hoxha's death on April 1985 revived hopes that finally Albania would follow the example of other communist countries, would end the international isolation and start up political, economic and social important reforms (Elez Biberaj, Albania in Transition, 2011, pg. 57).

His successor Ramiz Alia, was between "two fires", on one hand, conservative elements, guidance which had followed Hoxha, and on the other hand, liberal elements within the party.

However, even though Alia seemed to understand the economic, political and social problems of this situation, that the country was wallowing, Alia was not for radical reforms. Rather, he was for the continuation of Enver Hoxha's polizie (Elez Biberaj, 2011).

Faced with this situation, the Head of State cannot ignore the fundamental changes that were happening in other communist countries; therefore, he acted in a very careful manner with perestroika, opening the opportunities for tourism and the presence of the capitalist countries representatives in Albania (Antonello Biagini, 2005).

Foreign investments were enticed to the lack of public external debt, this due to an unprecedented isolation in history. Albanian regime also was included in the general crisis of the Balkan countries, the crisis caused by the collapse of the Berlin Wall in 1989.

Throughout the following year tensions in our country emerged, especially those of the student movement, which the government of the time tried to calm promising reforms and changes in foreign policy, getting access to the West, mainly the two neighboring countries, Italy and Greece at the same time hoping to collaborate with the European Economic Community.

Malile also raised the Kosovo's issue, who expressed his critical attitude for Yugoslavia's policy of the population in this region. Despite the willingness to strengthen the relations between our countries, The Minister of Foreign Affairs, could not mention the case of the Popa family that was considered a serious obstacle to sustain an improvement in bilateral relations. From his side Taviani confirmed Italy's interest in the progress of contacts between the two countries, at the same time he focused on concrete issues which he thought would be a first important step in this direction, as the strengthening of air and sea communication. 
Few days later after the meeting of both parties in Albania's capital, in May, the Alia's government decided to change attitude and give solution to the "Popa issue". Six brothers were able to leave the Italian Embassy and go to Italy. The positive outcome of this case was interpreted by many Albanians as a weaknes symptom of the communist regime. Furthermore, in light of the reforms promised by the Alia government, the population was currently experiencing a rapidly deterioration of economic conditions. The events taking place in the countries of the former Soviet bloc became the benchmark for some sectors of public opinion. At the same time the approach of Western television programs, especially the Italian, have played an important role in changing the attitude of Albania (Antonio Varsori, 2012, pg 615-635).

Departures from Albania through the foreign embassies, starting from that of Popa's brothers to the Italian Embassy, led Albania into the spotlight of the international press. It is interesting to note that the Italian Foreign Ministry was afraid that once the existing refugee situation would resolve positively, this episode would not affect the other Albanian citizens to seek refuge in Western embassies. As stated above it was confirmed with the massive floods in the western embassies that were operating in the Albanian capital.

Subsequent negotiations make possible the movement of thousands of Albanians directed to foreign countries. Faced with these facts the government of Tirana realized that they could worsen the relationships with Italy, Greece and other countries to which Alia hoped create a concrete plan of economic cooperation (Antonello Biagini, 2005).

According to the interpretation of Italian diplomacy, the events above described were used by the Communist Party, to undertake bold reforms.

\section{The Italian policies in confronting the illegal immigration}

In 1991 the final collapse of the communist regime in Albania, except the most dimensional changes caused by the massive migration of the Albanian population, this phenomenon forced the Italian political leadership to create a new policy, to deal with a neighbor which had been completely ignored for the last forty-five years, the public opinion also began to face the dramatic consequences of the collapse of communism in the Balkan countries. Albania has long been a traditional focus of the Italian foreign policy.

Attracted by the economic factor and by the hope to find a more quiet political environment, started in this way the Albanian exodus to the Italian coast, on 3 July 1990, the first persons that made a bid to cross Otranto, were six men aboard a raft, followed by 800 other people who had taken refuge in foreign embassies in Tirana during the first months of the chaos. 
In March 1991 began the "mass exodus" in the neighboring country, reaching more than 25,000 refugees, who were welcomed from the civil society, this due to lack of an organization by state structures.In early March 1991 had violent demonstrations, the authorities lost completely the control of the Harbor of Durres. Thousands of people aboard a ship whatever they could find and sail to the coast of Puglia, exactly where they landed. This dramatic development was completely unexpected for the Italian government and in a few days about 28,000 Albanians had arrived in Italy.

The Italian Parliament, on the $28^{\text {th }}$ of February 1990, approved the draft dated in December 30, 1989 n. 416. So in the following manner came into force the first law on immigration and asylum, otherwise known as "Martelli law". The present law in fact, did not provide a special protection, with the exception of persons persecuted for political reasons, because of race, religion, etc., as provided by the Geneva Convention. However, according to public opinion, the law was very liberal, even though supported on principle to regulate by law the illegal immigration. According to the data, the Italian government had a large number of asylum seekers, approximately 18,000, of which only 600 fulfill the objective criteria to obtain this status (George Santayana, Chi dimentica il passato è condannato a ripeterlo, fq 20$)$.

Almost immediately, the Italian government faced three main problems: a) to provide food and accommodation for the refugees, b) the issue of their treatment from a legal perspective, c) the development of a new policy towards Albania. As regarded by the provisions, Italian authorities raised refugee camps that temporarily located in Puglia. The government had decided to distribute the Albanian refugees in parks; the former barracks, etc, distributed in different regions.

Faced with this uncertain situation that dominated Albania after the collapse of communism and the massive arrival of refugees in the spring of 1991, Italy responded with a double intervention, military-military. In this way started the Pelikan operation, an international mission led by Italian soldiers.

At this phase the Italian public opinion was kind to the Albanian refugees. Some of them were hosted by Italian families, while the government was sharply criticized by both local authorities and the press for the inefficiency in coping with the emergency situation. Faced with this situation, on March 8, the Italian government gave a reply to the United Nations request "Do not repatriated the refugees", but faced with the exodus of Albanians. It was reassured that the refugees, who were at that moment in Italy, will not be repatriated. On the same time, the government was committed to find an appropriate solution which surpassed the emergency assistance and first reception (George Santayana, pg 21). 
Andreotti's government was somewhat scared that very soon the situation could change and the concession of the status as "political refugee" will convince Albanians to depart from their country. That was not the only cause, which would put the Italian state in front of the responsibility, the Yugoslav situation was deteriorating also, the Italian Leader were afraid that Italy wiould face a similar and serious phenomenon originating from Yugoslavia. In this conditions the Italian government should take concrete measures for coping with the situation, which was contradictory, on one side appear the solidarity of the Italian people towards the neighboring country while in Italy had entered into force the legal measures that were in contradiction with the italian solidarity.

Despite the goodwill of the Italian government to the phenomenon of Albanian refugees,it was concluded that the ultimate aim should be their own repatriation. However, the issue of emigrants was closely associated with "the hopeless situation of the Albanian people" and the general political situation in the country. In this context the main aim of Italy was in favor of democratization and stabilization of Albania.

The Italian government after appointing the Minister Margherita Bonvier as extraordinary commissioner for the issue of Albanian refugees, tried to stop the migration flows through a double intervention, blocking the boarding and simultaneously exerting pressure on the Albanian government to take concrete steps to stop this illegal phenomenon.

On such conditions in March of the same year, the Italian Vice Prime Minister Claudio Martelli reached Tirana, where he met with Fatos Nano (Fatos Nano was the Prime Minister of the new government appointed by Ramiz Alia).

The main negotiations between representatives of both countries were focused on the illegal immigration issue. Martelli was for an immediate solution, the repatriation of Albanian refugees. For the following reasons he attempted to persuade his homologue to prevent this phenomena, and to ensure that none of them would be subject of repressive measures. In Albania during this period were numerous problems, for this motive it was recommended to Nano to hold free elections as soon as possible (Similar requests were made by the Foreign Minister De Michelis, who met in Rome with his new albanian colleague, Kapllani).

On March 31 were held the first post-communist elections in Albania. Despite the huge willingness of the public opinion toward radicals changes, the elections showed that the Albanian population was not really prepared to be confronted with big changes. The winner of these elections was the Labour Party, due to the support of more conservative voters or in rural areas, while the opposition, the Democratic Party, led by a former communist, Sali Berisha, marked a tremendous success in the urban areas. In 
late April, Alia was elected President of the Republic, in May was created the government under the leadership of Fatos Nano. However, such developments were not able to resolve the dramatic problems that the country had, especially those of the economic and social character. The Albanian government created out of the new elections, together with the public opinion, called on to assist Italy and other Western countries, which ccould release Albania from the great economic depression. While Italy was trying to confront the urgent difficulties caused by the unexpected flux of thousands of refugees.

However, the Albanian situation was far from being stabilized. A new crisis exploded between the middle of July and beginning of August. In June, Fatos Nano was forced to step down, Ylli Bufi was appointed prime minister. He formed a "stability" coalition government.

\section{Confronting the situation and the diplomatic relations between our two countries}

According to the newspaper, L'Unita dated 13 June; the Italian Foreign Minister retaliated against the Albanian state by threatening with the refugees' situation. Massive flows of refugees have covered the Italian coast, therefore the foreign minister flied to Tirana to make clear the situation to the Albanian Government, if they do not take measures to prevent embarkation of the population, the Italian government would suspend the economic assistance. That was only one of the measures taken, otherwise Italy would not support Albania towards the integration into the European structures ( L’Unita, Giovedi 13 Giugno, 1991).

Differently from De Michelis, the extraordinary Commissioner simultaneously the minister for immigration, Margherita Bonvier indicates that somewhat the pacts with Tirana were respected, while the other side does not agree with the repressive measures taken by the government of Tirana. Because of these reasons, guidelines were given to the coastal marine, they may be helpful only when the clandestine life were at risk, in every other case, they should not infringe the Italian territory, because otherwise this would be a way to benefit for right of asylum.

During this period, new commotions erupted in many cities of Albania. Thousands of Albanians desperate of the economic, political and social situation approached the Italian coast. On August 8 the commercial ship, named "Vlora", was launched from the port of Durres at which were embarked about 20 thousand people. The early hours of the morning appeared on the horizon to the coast of Brindisi. arrived in Bari packed with thousands of refugees. The Prefect of Puglia, faced with the situation created, realized that he could not afford the large number of refugees made even more during the last month, the episode drew the public attention, both in 
Italy and outside the country. The Italian government chose a tougher line. The interventions to make possible the change of the itinerary of the ship to the city of Bari.

On August 11, began the operations of return. Two thousand of 'disobedient' people stood between the stadium and the port, willing to do everything, only not to return to Albania. While the Italian diplomacy set in motion, some government delegations visiting Albania, among them Margherita Boniver, Minister for immigration, which comes with a disturbing statement ... Make no mistake, they will come back to fifty thousand. So based on the Minister opinion, the measures undertaken should be put into life immediately; otherwise the Albanian emigration will not stop.

On August 13 the head of state Francesco Cosiga also visited Albania, whom before going towards Tirana, stopped in the prefecture of Bari. He expressed his indignation against the statement that was made by the mayor of Bari for the "Manifesto" newspaper. He expressed his dissent against the government in coping with the refugee crisis and the mistreatment that had been done to them by the Italian government (Nicola Mascellato, Una finestra nella storia 1991-1995, Edisud, Pg 42).

The foregoing refugees situation created problems within the Italian state, namely between the central and local government. However the situation created found a positive solution, where the mayor of Bari explained that, his statements were misunderstood, "the emergency has been treated in the humanitarian grounds, but in fact, that was not only a national problem but also a European one". So the refugee crisis transcends the borders, including indirectly third countries which need to come to the aid of Italy, as a member of the European Community.

After the consecutive appeals, part of the refugees who made resistance, were convinced on the empty promises that will stay in Italy. In fact the exact opposite happened, one day later, exactly on 17 August 1991, amounted to turn back in Albania. Even though in some way they succeeded, in fact even more for Italy the consequences were immense.

The Italian government compared to a few weeks ago, changed direction. It undertook strict policies against the number of refugees constantly increasing, was decided to turn them all back. But before landing, this number of people had to be dialed with concrete steps, to create a way to give the first assistance. In fact, despite the presence of police forces, the situation came out of control keeping the citizens of Bari and also the public opinion anxious. Under these circumstances, the only one solution for a large number of people was the City stadium, but this choice created an unmanageable situation.

The government of Tirana accepted to cooperate with the Italian government to prevent the landing of the refugees and their immediate 
return. The Italian government decided on a policy based on four main points: a) immediate repatriation of refugees, b) control of the closely coast, c) Immediate shipments of alimentary aids to Albania, d) the involvement of the European Community to solve the Albanian crisis.

\section{Conclusion}

In this research the focus was the identification of the Italian policy in confronting the Albanian refugee crisis. The Albanian mass exodus in the early 90' was seen as a crisis for the Italian state. There was not a concrete plan in this period, but Italy undertook casual policies, although they sometimes were contrary to the Italian political line. Faced with an uncertain situation that dominated Albania after the collapse of communism and the massive arrival of refugees in the spring of 1991, Italy responded with a double intervention, humanitarian -military, known as the Pelikan operation, an international mission led by Italian soldiers.

At this phase the Italian public opinion was kind to the Albanian refugees. Some of them were hosted by Italian families, while the government was very harsh.

The Italian Parliament, approved the first law on immigration and asylum, known as "Martelli law". The present law in fact, did not provide a special protection. However, according to public opinion, the law was very liberal, even though supported on principle to regulate by law the illegal immigration.

The Italian government, tried to stop the migration flows through a double intervention, blocking the boarding and simultaneously exerting pressure on the Albanian government to take concrete steps to stop this illegal phenomenon.

\section{References:}

Ambassador Gentilini 23-25 May 1987,Archive of the Albanian Ministry of Foreign Affairs, 1988, File 550, Minutes of, the appointment of Prime Minister Reiz Malile with Italian Minister of Labour, Formica, of 17 October 1988.

Antonio Varsori, (2012). Italy and the end of communism in Albania, 19891991 in Cold War History, Vol 12, nr 4, novembre.

Elez Biberaj, (2011) Albania in transition. The difficult road to democracy 1990-2000. Institute of International Studies, Tirana.

Kastriot Dervishi, (2006). The Albanian State History 1912-2005. State organization, political life, key events, all legislators, ministers and presidents swear state. Publishing House 55, Tirana. 
George Santayana, Who forget the past is condemned to repeat it, Asylum, between the third sector and the state: an difficult agreement but intensive, Edited by Italian Caritas and Migrantes Foundation.

Antonello Biagini, (2005). Contemporary History of Albania, Pocket Bompiani, Roma.

Agim Leka, Albanian migration during the post communist transition and the European integration in global era. An intercultural reflection, Academicus- International Scientific Journal MMXIII, 2013, pp 201-220, Retrieved fromhttp:/www.academicus.edu.al

Nicola Mascellaro, A window in the history 1991-1995, Edisud.

L'Unita, (1991).De Michelis menaces retaliation against Tirana. Thursday 13 June. 